\title{
Comparative exploration of learning styles and teaching techniques between Thai and Vietnamese EFL students and instructors
}

\author{
Nakhornsri Supalak, King Mongkut's University of Technology, Thailand \\ supalak.n@arts.kmutnb.ac.th
}

\begin{abstract}
Learning styles have been a particular focus of a number of researchers over the past decades. Findings from various studies researching into how students learn highlight significant relationships between learners' styles of learning and their language learning processes and achievement. This research focuses on a comparative analysis of the preferences of English learning styles and teaching techniques perceived by students from Thailand and Vietnam, and the teaching styles and techniques practiced by their instructors. The purposes were 1) to investigate the learning styles and teaching techniques students from both countries preferred, 2) to investigate the compatibility of the teaching styles and techniques practiced by instructors and those preferred by the students, 3) to specify the learning styles and teaching techniques students with high level of English proficiency preferred, and 4) to investigate the similarities of Thai and Vietnamese students' preferences for learning styles and teaching techniques. The sample consisted of two main groups: 1) undergraduate students from King Mongkut's University of Technology North Bangkok (KMUTNB), Thailand and Thai Nguyen University (TNU), Vietnam and 2) English instructors from both institutions. The instruments employed comprised the Students' Preferred English Learning Style and Teaching Technique Questionnaire and the Teachers' Practiced English Teaching Style and Technique Questionnaire. The collected data were analyzed using arithmetic means and standard deviation. The findings can contribute to the curriculum development and assist teachers to teach outside their comfort level to match the students' preferred learning styles. In addition, the findings could better promote the courses provided for students. By understanding the learning style make-up of the students enrolled in the courses, faculty can adjust their modes of content delivery to match student preferences and maximize student learning. Finally, this research could establish better understanding between language learning natures of people from Thailand and Vietnam.
\end{abstract}

Key words: learning styles, teaching styles, teaching techniques, EFL

\section{Introduction}

Students normally learn something in different ways. Some could learn best by seeing and hearing, reflecting and acting, reasoning logically and intuitively, analyzing and visualizing, and others steadily and in fits and starts (Felder, 2002). 
These students' ways of learning are termed learning styles. According to Alkhasawe et al. (2008), learning styles are personal qualities that influence the way students interact with their learning environment, peers, and instructors. However, it is inevitable that teaching styles and teaching techniques implemented by instructors are diverse. Some instructors prefer to lecture and others demonstrate or discuss; some focus on principles and others on applications; some emphasize memory and others understanding. The compatibility of students' learning styles and the instructors' teaching styles and techniques may yield fruitful learning outcomes (Felder \& Silverman, 1988). Consequently, a match between instructors' teaching styles and students' learning styles should be well recognized since it could possibly allow students to gain a deep understanding of the lessons due to the appropriate teaching techniques provided.

Once students have their own learning styles, likewise the instructors do. As a result, the instructors usually implement their own teaching styles in class. No model of instruction would be the best for all situations. Katz (1996) explains that teaching styles are a complex construct referring both to teachers' beliefs and actions. When a number of teachers' actions are arranged into varying patterns in order to create specific learning environments for students, it is possible to specify a particular teaching style.

In fact, most of the learning and teaching styles parallel each other. A student who favors intuitive over sensory perception, for example, would respond well to an instructor who emphasizes concepts (abstract content) rather than facts (concrete content); a student who favors visual perception would be most comfortable with an instructor who uses charts, pictures, and films. Dimensions of learning and teaching styles shown in Table 1 illustrate the commonality of the preferred learning styles and the corresponding teaching styles.

Since individuals have their own varied and preferred ways of learning. In every course, teachers should look for opportunities to connect to and use each of these styles to help students to be successful. Generally, students tend to employ one of the main learning styles shown above, but they can also adapt to another style if necessary. However, learners are likely to look for their preferred style in each learning situation mostly because they associate that style with learning success. When designing or teaching a course, teachers should seek to incorporate learning experiences and activities that appeal to each individual's learning style in order to increase the likelihood of learner success.

Felder and Silverman (1988) whose study is on the compatibility of engineering students' learning styles and the instructors' teaching styles found mismatches between common and traditional learning styles of students and traditional teaching styles of engineering professors. 
Table 1: Dimensions of Learning and Teaching Styles

\begin{tabular}{|c|c|c|c|}
\hline \multicolumn{2}{|c|}{ Preferred Learning Style } & \multicolumn{2}{|c|}{ Corresponding Teaching Style } \\
\hline Sensory & & Concrete & \\
\hline & Perception & & Content \\
\hline Intuitive & & Abstract & \\
\hline Visual & & Visual & \\
\hline Auditory & Input & Verbal & Presentation \\
\hline & Organization & & Organization \\
\hline Deductive & & Deductive & \\
\hline Active & Processing & Active & Student \\
\hline Reflective & & $\begin{array}{l}\text { participation } \\
\text { Passive }\end{array}$ & \\
\hline Sequential & & Sequential & \\
\hline Global & Understanding & Global & Perspective \\
\hline
\end{tabular}

(Felder \& Silverman, 1988)

In consequence, students become bored and inattentive in class, do poorly on tests, get discouraged about the courses, the curriculum, and themselves, and in some cases change to other curricula or drop out of school. Professors, confronted by low test grades, unresponsive or hostile classes, poor attendance and dropouts, know something is not working; they may become overly critical of their students or begin to wonder if they are in a right profession.

The compatibility of the learning and teaching styles influences learning processes. Instructors who adapt their teaching style to suit students' preferred learning styles should come close to providing an optimal learning environment for most students in a class (Felder \& Silverman, 1988). One common discrepancy is that most people, college age and older, are visual learners (Barbe \& Milone, 1981), while most college teaching is verbal. A second learning/teaching style mismatch exists when the preferred input modality of most students and the preferred presentation mode of most professors are inconsistent (Felder \& Silverman, 1988).

Practically, teaching styles are linked to teaching techniques. Dullien and Priewe (2010) suggested that teaching techniques include a detailed list of rules or a guideline for any teaching activity. It is based on the description of steps, or a set of do's and don'ts. Felder (2002) proposed the compatibility of the students' learning styles and teaching techniques such as the provision of a balance of 
concrete information (facts, data, real or hypothetical experiences and the results) should be arranged for students who prefer sensory learning styles. With this, instructors should attempt to match teaching styles and techniques to students' preferred learning styles, not just promoting understanding in a classroom setting. The retained compatibility is likely to lead to a higher level of understanding (Wittmann-Price \& Godshall, 2009). Moreover, information that is delivered in a style that matches the students' learning styles promotes understanding, leading to the retention of new information at a conceptual level, which is not surface learning that only requires memorization (Bastable, 2008).

On the other side, discounting learning styles can lead to bored, unresponsive class participants, which in turn affects grades and attendance rates, therefore, leading to a loss in satisfaction (Alkhasawe et al., 2008). Learners make the most out of information when they can select information and organize it into representations that make sense to them (Jonassen, 1999).

Since the regional political policy in Southeast Asia could be an important factor providing a great impact to the educational development, the establishment of ASEAN Economic Community (AEC) in the upcoming year could certainly influence developing plans within the region in many ways, especially in education. AEC consisting of 10 ASEAN member countries comprising Brunei Darussalam, Cambodia, Indonesia, Laos, Malaysia, Myanmar, The Philippines, Thailand, Singapore and Vietnam will be united as a community for the cooperation including human resources development and capacity building; recognition of professional qualifications; closer consultation on macroeconomic and financial policies; trade financing measures; enhanced infrastructure and communications connectivity; development of electronic transactions through eASEAN; integrating industries across the region to promote regional sourcing; and enhancing private sector involvement for the building of the AEC. A lot of action plans have timelines. A number of actions have already started and some have completed, but most are underway and have to be ready by the end of 2015 .

Thailand stands ready to take a leading role in conducting the development cooperation with other countries both in bilateral and trilateral forms. Thailand's support has been designed in accordance with specific needs of each ASEAN country which ultimately will contribute to the strengthening of the ASEAN Community in the three pillars: political-security, economic, and socio-cultural, as well as the implementation of the Master Plan on ASEAN Connectivity (n.d.).

However, after seeing no concrete move towards preparing for the AEC by the government, Vongsinsirikul (Thai-AEC, n.d.), director of Dhurakij Pundit University's ASEAN Community Preparation Centre (ACPC) mentioned that foreign languages, English in particular, are Thai people's big problem. But we can learn them since we need to communicate with people from ASEAN countries that we are going to work with. The government should put preparations for the AEC 
on the national agenda. The ministry should find more people with English communication skills and let them teach at schools. The curricula revamp should encourage students to think analytically and be able to solve problems so they are able to handle problems when growing up. Teachers should study and understand the ways of life and cultures of other ASEAN countries.

As Vietnam is one of ASEAN country members, it has since put in place a number of measures and is gearing up well for regional competition. The business community, as well as academics and other individuals are under pressure to institute reforms and increase competitiveness ahead of AEC $(\mathrm{Vu}, 2013)$. Importantly, the Faculty of Applied Arts, King Mongkut's University of Technology (KMUTNB), Thailand and International School, Thai Nguyen University (ISTNU), Vietnam have signed the Memorandum of Understanding (MOU) for the academic co-operative activities. One of the important cooperative activities that the two institutes can implement for mutual benefits and may contribute to an enduring institutional linkage for education cooperation is particularly doing collaborative research.

To accomplish this, the present study includes the sample from both KMUTNB and ISTNU. The findings obtained will be able to provide better understanding not only for Thai students and instructors, but also for Vietnamese students and instructors. This would serve to fulfill the aim of AEC establishment, which is to develop the bilateral relationship between the two countries.

To address this identified need, this study aims at investigating the English learning styles Thai and Vietnamese students prefer, finding out Thai and Vietnamese students' preferred English teaching techniques, investigating the compatibility of the teaching styles and teaching techniques practiced by Thai and Vietnamese instructors and those preferred by the students, and specifying the English learning styles and teaching techniques students with high level of English proficiency prefer in order to investigate if these students' preferences are consistent with the teachers' practice.

In addition, the researcher is interested in further exploring if the students from Thailand and Vietnam report similarities regarding their preferences for learning styles and teaching techniques.

\section{Literature review}

This section reviews the concepts of learning styles, teaching styles, and teaching techniques. Importantly, situations of English teaching in Thailand and Vietnam are also explored. Finally, previous studies relevant to learning styles, teaching styles and teaching techniques are included.

\subsection{Learning styles}


Learning styles can be defined as the way one likes to learn. Leaning styles are put into practice by particular learning strategies (Ehrman, 1996). Dunn and Griggs (1988) refer learning styles to “...the biologically and developmentally imposed set of characteristics that make the same teaching method wonderful for some and terrible for others" (p.3). According to such researchers as Keefe (1987), Kinsella (1995), Oxford and Anderson (1995)], Provost and Anchors (1987], learning styles are composed of six interconnected features:

1. The cognitive feature includes preferred or habitual patterns of mental functioning: information processing and the formation of ideas and judgments (often referred to as cognitive styles).

2. The executive feature is the extent to which learners look for order, organization and closure in managing the learning processes.

3. The affective feature consists of the patterns of attitudes, beliefs, values and interests that influence what a person will attend to in a potential learning situation.

4. The social feature relates to the preferred degree of involvement with other people while learning.

5. The physiological feature involves what are at least partly anatomically based sensory and perceptual tendencies of the learners.

6. The behavioral feature concerns the learners' tendency to actively seek situations compatible with their own learning preferences.

According to Cohen and Weaven (2005), learning styles are not particular qualities in each individual's personality, but they are only preferences which can be changeable. If the classroom environment suits their learning styles, students are likely to learn better. If language material, for example, is delivered in several different ways, that means learning styles of various students in a class are more likely to be taken into consideration. To illustrate this, Cohen and Weaver suggest that the present and past perfect tenses in the target language should be taught by having students listen to the recording and then draw a chart in their notebook of a timeline that details when to use each form of tenses. If so, both ways serve both the auditory and visual learners.

Felder (2002) further categorizes learning styles into five main types.

1. Perception: Types of information students preferentially perceive

- Sensory involves observing, gathering data through senses (Jung, 1971).

Sensors like facts, data, and experimentation. They prefer solving problems by standard methods and dislike "surprise". Normally, they are patient with detail but do not like complication. They are good at memorizing facts. They are generally careful but may be slow. Their slowness in translating words puts them at a disadvantage in timed tests since they may have to read 
questions several times before beginning to answer them, they frequently run out of time (Mayer, 1996).

- Intuition involves indirect perception by way of the unconscious-speculation, imagination, hunch (Jung, 1971). Intuitors prefer principles and theories and innovation and dislike repetition. They can be bored by details and welcome complication. However, they are good at grasping new concepts. Generally they are quick but may be careless. Intuitors may do poorly on timed tests but for a different reason - their impatience with details may induce them to start answering questions before they have read them thoroughly and to make careless mistakes (Mayer, 1996). Fischer and Fischer (1979) stated that these students do not follow traditional logic, chronology or step-by-step sequence.

2. Input: Sensory channels (touch, taste, and smell) through which external information is most effectively perceived (Felder, 2002).

- Visual learning style includes sights, pictures, diagrams, symbols. They remember best what they see: pictures, diagrams, flowcharts, time lines, films, demonstrations. If something is simply said to them they will probably forget it.

- Auditory learning style means sounds or words. Auditory learners remember much of what they hear and more of what they hear and then say. They get a lot out of discussion, prefer verbal explanation to visual demonstration, and learn effectively by explaining things to others.

- Kinesthetic involves taste, touch and smell. Kinesthetic learners prefer both information perception (touching, tasting, smelling) and information processing (moving, relating, doing something active while learning).

\section{Organization: Organization of information which the student is most comfortable with (Felder, 2002)}

- Inductive is a reasoning progression that proceeds from particulars (observations, measurements, data) to generalities (governing rules, laws, theories). Inductive students learn from observing the world around them and draw inferences.

- Deductive proceeds in the opposite direction. In induction one infers principles; in deduction one deduces consequences. Deductive learners learn best from principles to phenomena.

4. Processing: Ways students prefer to process information (Felder, 2002)

- Active means doing something in the external world with the information discussing it or explaining it or testing it in some way. Active learners are someone who feels more comfortable with, or are better at, active 
experimentation through reflective observation, and conversely, for a reflective learner. They do not learn much in situations that require them to be passive (such as most lectures). However, they work well in groups and tend to be an experimentalist.

- Reflective involves examining and manipulating the information introspectively. Reflective learners do not learn much in situations that provide no opportunity to think about the information being presented (such as most lectures). They work better by themselves or with at most another person. Learners of this style tend to be a theoretician.

5. Understanding: Ways students progress toward understanding (Felder, 2002)

- Sequential means students who are comfortable with the presentation of material in a logically ordered progression, with the pace of learning dictated by the clock and the calendar. When a body of material has been covered, the students are tested on their mastery and then move to the next stage. Sequential students follow linear reasoning processes when solving problems. They can work with material when they understand it partially or superficially. They may be strong in convergent thinking and analysis. Students of this learning style can learn best when material is presented in a steady progression of complexity and difficulty.

- Global: Students who may be lost for days or weeks, unable to solve even the simplest problems or show the most rudimentary understanding, until suddenly they get it- the light bulb flashes, the jigsaw puzzle comes together. They may then understand the material well enough to apply it to problems that leave most of the sequential learners baffled.

Global students make intuitive leaps and may be able to explain how they came up with solutions. They may have great difficulty working with material when they understand it partially or superficially. These students may be better at divergent thinking and synthesis and sometimes do better by jumping directly to more complex and difficult material. They do not learn in a steady or predictable manner, but they tend to feel out-of-step with their fellow students and incapable of meeting the expectations of their teachers.

When they are struggling to master material with which most of their contemporaries seem to have little trouble, they may feel stupid. Some eventually become discouraged with education and drop out. Global students are the synthesizers, the multidisciplinary researchers, the systems thinkers, the ones who see the connections no one else sees. They can be truly successful if they survive the educational process. 
From the above, we as teachers should be aware that every individual learns differently and thus has a unique learning style. However, learning styles are preferences which can be altered. Understanding of the ways students prefer to learn English can provide guidelines for improving learning and teaching EFL.

\subsection{Teaching styles}

Teaching styles may be defined as types of information emphasized by the instructor: concrete- factual, or abstract-conceptual, theoretical, modes of presentation stressed; visual-pictures, diagrams, films, demonstrations, or verbal- lectures, readings, discussions, the ways that presentation organized: inductively-phenomena leading to principles, or deductively - principles leading to phenomena, modes of student participation facilitated by the presentation; active-students talk, move, reflect, or passive-students watch and listen, and lastly types of perspective provided on the information presented: sequential-step-by-step progression (the trees), or global-context and relevance (the forest) (Felder, 2002).

Similarly, Fischer and Fischer (1979) defined teaching styles as a classroom made, a pervasive way of approaching the learners that might be consistent with several methods of teaching. Katz (1996) also explained that teaching styles is a complex construct referring both to teachers' beliefs and actions. When a number of teachers' actions are arranged into varying patterns, creating specific learning environments for students, it is possible to talk about a particular teaching style. Still, it is questionable whether the observable style is the result or the cause of classroom behaviour.

Felder (2002) specified five categories of teaching styles as follows:

1. Content: Types of information emphasized by the instructors

1.1 Concrete: denotation of factual knowledge transmission

1.2 Abstract: preference for theoretical information

2. Presentation: Stressed modes of presentation

2.1 Visual: utilization of pictures, diagrams, films and demonstrations extensively

2.2 Verbal: having many lectures, readings and discussions

2.3 Kinesthetic: using both information perception (touching, tasting, smelling) and information processing (moving, relating, doing something active while learning) in the instruction.

3. Organization: Ways to organize the presentation

3.1 Inductive: Presenting particulars (observations, measurements, and data) to generalities (governing rules, laws, theories). (Phenomena leading to principles) (Teachers may assign them to observe the things around them and draw inferences.)

3.2 Deductive: Presenting principles to phenomena 
4. Student preparation: Modes of student presentation facilitated by the presentation

4.1 Active: Allowing students to talk, move and reflect

4.2 Passive: Having students to watch and listen

5. Perspective: Types of perspectives provided on the information presented

5.1 Sequential: The presentation of material in a logically ordered progression, with the pace of learning dictated by the clock and the calendar. When a body of material has been covered, the students are tested on their mastery and then move to the next stage. Generally, teachers of this style tend to allow students to follow linear reasoning processes when solving problems, or have them work with material when they understand it partially or superficially. They also have convergent thinking and analysis and prefer to present material in a steady progression of complexity and difficulty.

5.2 Global: Divergent thinking and synthesis. These teachers have students jump directly to more complex and difficult material. Teachers also realize that students do not learn in a steady or predictable manner and they tend to feel out-of-step with their fellow students and incapable of meeting the expectations of their teachers. They may feel stupid when they are struggling to master material with which most of their contemporaries seem to have little trouble. Some eventually become discouraged with education and drop out. Moreover, these teachers like to arrange the activities which allowing students to be synthesizers, the multidisciplinary researchers, the systems thinkers, the ones who see the connections no one else sees. They can be truly successful if they survive the educational process.

In brief, teaching styles can classify instructional techniques according to how well instructors address the proposed learning style component. Thus, learning styles and teaching styles are closely interrelated.

\subsection{Teaching techniques}

A teaching technique is implementational and it is something that actually takes place in language teaching or learning in the classroom. It is a detailed list of rules or guidelines for any activity. It is based on the description of steps, or a set of do's and don'ts, and can often be linked to a method or strategy (Dullien \& Priewe, 2010).

Felder (2002) suggests that students' learning styles and teaching techniques should be compatible so that it could make instruction more effective. This researcher also suggested teaching techniques for each learning style as follows:

1. Perception consists of two types of learning styles: sensory and intuition

(Felder, 2002). 
1.1 For sensors, they should be provided with a balance of concrete information (facts, data, real or hypothetical experiences and their results). The balance material should emphasize practical problem-solving methods. Explicit illustrations of sensing patterns, observation of surroundings, empirical experimentation, and attention to detail will be best to increase the sensors' understanding. They tend to respond well when using computer-assisted instruction-sensor.

1.2 Intuitors prefer to be taught by a balance of abstract (principles, theories, mathematical models). The balance material should emphasize fundamental understanding. They should be provided by explicit illustrations of intuitive patters (logical inference, pattern recognition, generalization). They tend to prefer creative solutions, even incorrect ones.

2. Input: Students who prefer this type of learning style most effectively learn external information by touching, tasting, and smelling through which external information is most effectively perceived.

2.1 Visual learners should learn through pictures, schematics, graphs, and simple sketches liberally before, during and after the presentation of verbal material. Teachers should show films. Teachers should provide them demonstrations, hands-on, if possible. These students will value to-do lists, assignment logs, and written notes (Carbo, Dunn \& Dunn, 1986).

2.2 Auditory learners will learn best when teachers use a lecture-style forum, presenting information by talking to their students. Regulating voice tone, inflection, and body language will help all students maintain interest and attention. Auditory learners succeed when directions are read aloud, speeches are required, or information is presented and requested verbally (Carbo, Dunn \& Dunn, 1986).

2.3 Kinesthetic learners prefer to engage with the learning activity such as in a science lab, drama presentation, skit, field trip, dance, or other active activity. A more hands-on approach: manipulatives and other "props" are incorporated into almost every subject (Stafford, Dunn \& Bacon, 1993).

3. Organization includes inductive and deductive learning styles. The appropriate techniques for these learning styles are proposed here (Felder, 2002).

3.1 Inductive learners can learn best when the material is presented to what has come before and what is still to come in the same course, and particularly to the students' personal experience. Teachers present theoretical material and then develop the theory.

3.2 Deductive people prefer to know how the theory is validated and deduce its consequences and present applications.

4. Processing consists of two main types of learning styles: active and reflective (Felder, 2002 ). 
4.1 Active learners prefer to study with material that emphasizes practical problem-solving methods. They should be provided with demonstrations, hands-on, if possible. Computer-assisted instruction is recommended. Much opportunity should be provided for them to do something active besides transcribing notes. Small-group brainstorming activities that take no more than five minutes are extremely effective for this purpose. Teachers should give students an option for cooperating in homework assignments to the greatest possible extent. Active learners generally learn best when they interact with others; if they are denied the opportunity to do so, they are being deprived of their most effective learning tool.

4.2 Reflective learners like to learn with material that emphasizes fundamental understanding. Teachers should not fill every minute of class time lecturing and writing on the board. They should provide intervals-however brief-for students to think about what they have been told.

5. Understanding includes the ways students progress toward understanding (Felder, 2002). The learning styles for understanding are sequential and global. The recommended techniques which fit their styles can be summarized here.

5.1 Sequential learners should be presented with theoretical material. Then, teachers should allow them to develop the theory. They prefer to learn how the theory is validated and deduce its consequences and present applications.

5.2 Global people prefer to relate the material being presented to what has come before and what is still to come in the same course, to material in other courses, and particularly to their personal experience. Teachers should assign some drill exercises to provide practice in the basic methods being taught but do not overdo them. Also, they should be provided with some open-ended problems and exercises that call for analysis and synthesis. Creative solutions, even incorrect ones should be applauded.

When instructional processes are implemented, classroom will continue to integrate more these techniques. When students understand their learning styles, they can better adapt to their learning environment. Thus, once a student's unique learning style is indentified, the teacher can begin to build upon it. Understanding learning styles is only the first step in maximizing potential and overcoming learning differences.

\section{English teaching situations in Thailand and Vietnam English teaching situations in Thailand}

Generally, Thai students spend twelve years studying English from primary and secondary schools, but their English ability is still questionable. When compared to people in neighboring countries, their English proficiency is relatively low. The 2010 Test of English as a Foreign Language (TOEFL) showed that 
Thailand ranked $116^{\text {th }}$ out of 163 countries. In the 2011 report, the Thai average score was still low, which is 75 (Test and Score Data Summary for TOEFL, 20112012). However, these poor results were controversial. Some doubted the consistency and validity of the tests, while others questioned the teaching and learning practices in English-language classes in Thai schools (Noom-ura, 2013).

As for the causes of failure upon examining the English-language classes, many researchers pointed to a few main factors contributing to the failure of Englishlanguage teaching-and-learning: unqualified and poorly-trained teachers, poorlymotivated students, learners of mixed abilities in overly large classes, and rare opportunities for student exposure to English outside of class time. These are considered the causes of difficulties in English language teaching and learning in Thailand especially in the primary and secondary schools. Some of the problems posted were: teachers' heavy teaching loads, inadequately equipped classrooms and education technology, the university entrance examination system, teachers' insufficient English language skills and cultural knowledge. The problems involving students who wished to speak English fluently included challenging interference from Thai language, lack of opportunity to use English in their daily lives, unchallenging English lessons, being passive learners, being too shy to speak English with classmates, being poorly-motivated and lack of responsibility for their own learning. These problems have been attributable to the unsatisfactory results of English language teaching as mentioned earlier. However, the most important factor in student learning progress is the teachers and teacher quality which outweigh other factors such as motivation, funding, and class sizes. Qualified teachers can create the best environment for learning.

As for Thailand, a survey, in collaboration with the University of Cambridge, measuring the qualifications of four hundred Thai teachers of English, found that a full $60 \%$ of them had knowledge of English and teaching methodologies below that of the syllabus level at which they were teaching. Of the remaining top $40 \%$, only $3 \%$ had a reasonable level of fluency, and only $20 \%$ were teaching class-levels for which they were both qualified and competent.

In addition to the lack of qualified teachers, it is widely understood that what is expected from teachers these days is multi-faceted. They are required to teach effectively in challenging environments; to make effective use of information and communications technology (ICT) in their teaching; to cater to a variety of learning styles; to conduct research aimed at improving the quality of their teaching; and to deal effectively with multitudinous administrative tasks -- all of which are to meet up with the requirements for 'Quality Assurance.'

Moreover, most Thai teachers of English, especially at the secondary level, have to teach at least eighteen hours a week on average and often take on additional classes outside regular school hours in order to supplement their relatively meager salaries. Because of overloaded burden, their teaching styles start to 
fossilize into ones of rote-learning, teaching grammar and translation with Thai as the medium of instruction, teacher-centered classroom activities, spoon-feeding, and so on.

In an attempt to improve the situation, institutions of higher education realize this fact and try to give assistance by organizing training sessions, seminars, and conferences for teachers at all levels of ability and experience: novice teachers, teachers with some experience, and teachers able to play more advanced roles as leaders or trainers. Also, the Thailand Education Reform implemented between 1996 and 2007 emphasized teacher development, and teachers would be offered continuous training with some form of training such as attending seminars, workshops, or conferences every two years (Wiriyachitra, 2002).

However, the design and the implementation of professional development training courses, which focused mainly on lesson-planning and teaching methodology, emphasizing how to teach each skill and how to teach integrated skills, were in a sort of top-down and non-collaborative manner. In other words, teacher participants had no opportunity to influence or change the content or delivery of the professional development activities and materials being provided. Colbert, Brown, Choi and Thomas (2008) stated that improving teacher quality is both common and necessary, and it depends on professional development, which should create meaningful learning experiences for teachers.

Apart from the teacher quality, the student motivation, the curricula and textbooks, the assessment methods, and other supporting factors such as teaching aids, class sizes, and time allocation are often said to exacerbate the English language teaching problems in Thailand. Thus, with the present unsatisfactory results of English language teaching and learning and obvious desires for professional development of English teachers, the researcher aimed to identify a clearer picture of the problems teachers are facing and to find out if those teachers need any kind of professional development.

\subsection{English teaching in Vietnam}

Vietnam general education consists of three levels with 12 forms/grades: primary level (from Form 1 - 5 for children aged 6 to 11); lower secondary level (from Form 6 - 9 for children aged 11 - 15); and upper secondary level (from Form $10-12$ for children aged $15-18$ ).

English was introduced nationally as a compulsory subject at upper secondary level and as an elective subject at lower secondary level. In this period, two sets of English textbooks were concurrently used in Vietnamese schools: the 3-year set (for students who started learning English from Form 10-12) and the 7-year set (for students who started learning English from Form 6 -12). The final upper secondary school exam, however, was based on the knowledge and skills required in the 3-year set. Both sets of textbooks, although differing in orientation, are 
mainly grammar-based, taking the view that grammar can be taught systematically as a set of rules to be mastered and transferred by the learner into proficient language use. While they take cognizance of the significant place of reading comprehension and oral skills, the grammar sections in each unit tend to dominate.

Van Van (2010) also states the problems in teaching English in Vietnam as follows:

Firstly, there is a disproportionate demand-supply. With a population of over 85 million, of whom a sizeable proportion has a strong desire to learn English, the demand for English language teaching far outstrips the supply of native speaker and competent non-native speaker teachers.

Secondly, textbook writing and teacher retraining are the two important aspects to implement English curriculum. Textbook writing has been completed, but to do massive and long term retaining of teachers in English competence would demand manpower and logistic resources beyond the capacity of the system at present.

Thirdly, despite the importance of English in the new context of integration and globalization, English language teaching in Vietnam, due to its low quality, has not met the demand for competent English-speaking people. The main reasons are that (1) most of the English teachers, particularly those who are teaching at primary and lower secondary levels are disqualified, (2) most teachers, except some who are teaching at tertiary level, have not had a chance to study in an English-speaking country, and (3) many of them do not normally communicate in English and cannot sustain teaching that mainly depends on communicative interactions.

Fourthly, there are classroom constrains: schools are often located in noisy places, with poor ventilation, overloaded beyond their capacity to classes of fifty or even sixty, with poor libraries and poorly paid staff.

Fifthly, although the rhetoric of the Vietnamese Ministry of Education and Training stresses the development of practical communication skills, this is rarely reflected at the classroom level, where the emphasis is on the development of reading comprehension, vocabulary and structural patterns for the purposes of passing the end-of-school and university entrance examinations into colleges or universities.

Sixthly, there is a mismatch between testing and teaching in English language teaching in Vietnam. While teaching follows the communicative approach, testing seems to focus on measuring students' lexicogrammatical knowledge. To make matters more complex, at tertiary level, what the Vietnamese tertiary institutions do is to adopt either TOEFL or TOEIC or IELTS as the main yardstick to measure the students' knowledge and skills in English. These instruments, as is known, are suitable for measuring the knowledge and skills of English of those students who 
are going to study either in Britain or in the USA or in an English-speaking country. And finally, the fact that English is introduced into primary schools in Vietnam makes some people express their concern about the negative effects that early introduction of English is having on national identity (Nunan, 2003).

\subsection{Previous studies}

A number of studies on learning styles have been done over the decades both in Thailand and other countries. The related studies below report the findings obtained from ESL and EFL students.

Mulalic, Shah, and Ahmad (2009) investigated perceptual learning styles of students in English as a second language (ESL) situation in Malaysia. The differences in learning styles of the students according to their gender and ethnicity were also examined. Reid's (1995) PLSPQs were employed. The results revealed that the students' preferred learning style was Kinesthetic. They expressed minor preferences for Visual, Auditory and Group learning styles, whereas they showed negative preferences toward Individual and Tactile learning styles. There was a significant difference in learning styles between male and female students regarding Auditory and Kinesthetic learning styles. The mean scores for the males were higher in both cases, which means that they favored Kinesthetic and Auditory learning styles when compared to their female counterparts. Significant differences in all learning styles among Malay, Chinese and Indian ESL students were also found. The authors concluded that it is important to determine learning styles of the students and that there should be an effort from the educator's side to accommodate those differences in the classroom.

In Thailand, Akkakoson (Akkakoson, 2011) studied the perceptual learning style preferences of Thai EFL university students of science and technology disciplines. The results indicate that these students have identifiable learning styles that differ among them. They favor Group learning style the most and Individual learning style the least. Not all of the factors studied are found to contribute to the choice of learning styles; only the age and English learning experience are. Preferences for learning styles actually fluctuate within the course. Thai teachers of English are found to be Visual learners/teachers and Group learning is their least favorite style. Interestingly, a mismatch between student learning styles and teacher teaching styles is found. Both the students and the teachers unanimously agree on further views on learning and teaching styles, and the teachers generally agree on Reid's (1995) major and minor hypotheses. A balanced style of teaching in order to accommodate diverse learning styles in the classroom is highly recommended.

These two studies focus on the preferences or the perception of learners in learning styles and teachers' teaching styles. Mulalic et al. (2009) pointed out that factors such as gender and ethnicity can allow different learning styles. Akkakoson 
(2011) also illustrated the mismatch between students preferred learning styles and teachers' preferred teaching styles. This finding is similar to Katsioloudis and Fantz's study (2012) who investigated the preferred learning and teaching styles for Engineering, Industrial, and Technology Education students. This study illustrated that while there was some variation within majors, the overall dominant learning style in the materials process course was the kinesthetic style. While this was a result the researchers expected, the technology education students were unexpected outliers from the rest of the group. According to the study, the dominant preferred teaching style of the faculty members who taught the materials process course was the kinaesthetic style. The researchers suggest that this is due to the learning style and comfort zone of the faculty. In essence, faculty members are teaching the way they were taught.

The similar recommendations obtained from these previous studies are to balance teaching styles to accommodate diverse learning styles. Literally, these reviewed studies mainly studied the preferences of both learning styles and teaching styles reported by students and instructors. The focus of the present study, on the other hand, took consideration of the teaching styles and teaching techniques practiced in classroom setting. The instructors participated in this study were asked to report their actual teaching styles and techniques implemented while teaching. Then, the match between the preferred learning styles reported by students and the teaching styles and techniques practiced by instructors could be investigated.

\section{Methodology}

\subsection{Research questions}

The study addresses the following research questions:

1. Which English learning styles and teaching techniques are preferred by Thai and Vietnamese students?

2. Which teaching styles and teaching techniques practiced by Thai and Vietnamese teachers can be matched with those preferred by the students?

3. Which English learning styles and teaching techniques are preferred by students with high level of English proficiency?

4. What are the similarities of Thai and Vietnamese students' preferences for learning styles and teaching techniques?

\subsection{Limitations of the study}

One limitation of the present study is that the participants of undergraduate university students in both sampled institutions were selected by purposive method. Therefore, the results of the study may not be generalizable beyond these groups. 


\subsection{Participants}

Since there are two main groups included in this study, the sampling techniques used are as follows:

1) For the student group, 50 Thai and Vietnamese students from KMUTNB and ISTNU were randomly selected and used as subjects. Totally, 100 students studying Industrial Management, Computer Design and International Business Administration are invited to participate in this study.

2) Regarding the teacher group, the sample included an intact group of six teachers who were purposively selected from native and non-native English teachers working at KMUTNB and ISTNU.

\subsection{Research instruments}

The instruments included 1) the Students' Preferred English Learning Style and Teaching Technique Questionnaire (SPELS-TTQ), 2) the Teacher's Practiced English Teaching Style and Teaching Technique Questionnaire (TPETS-TTQ), and 3) English proficiency test used for specifying students' English proficiency levels (EPT).

The instruments were developed according to the dimensions of learning styles, teaching styles and teaching techniques suggested by Felder (2002) and Felder and Silverman (1988). These researchers posit that the compatibility of the learning styles, teaching styles and teaching techniques are very crucial. Thus, the corresponding teaching style and teaching technique to each learning style are strongly recommended. The present researcher therefore adopts these recommended corresponding learning styles, teaching styles and techniques as the conceptual framework for examining the compatibility of the learningteaching style construct in this study. The following table illustrates the adopted framework with detailed descriptions.

Table 2: Summary of the conceptual framework for developing the two questionnaires

$\begin{array}{llc}\text { Learning Style } & \begin{array}{l}\text { Corresponding } \\ \text { Teaching Style }\end{array} & \begin{array}{c}\text { Corresponding Teaching } \\ \text { Technique }\end{array}\end{array}$

1. Perception-

Sensory: observing, gathering data through senses
1. Content-Concrete:

denotation of factual knowledge transmission
1. Perception-Sensory:

- Provide a balance of concrete information (facts, data, real or hypothetical experiences and their results

- Balance material that emphasizes practical problemsolving methods

- Provide explicit illustrations of sensing patters (observation of 


\section{Perception-}

Intuition: indirect perception by way of the unconsciousspeculation, imagination, hunches

\section{Content- Abstract:} preference for theoretical information

surroundings, empirical experimentation, attention to detail)

- Use computer-assisted instruction-sensors respond very well to it.

\section{Perception- Intuition:}

- Provide a balance of abstract concepts (principles, theories, mathematical models.)

- Balance material that emphasizes fundamental understanding.

- Provide explicit illustrations of intuitive patters (logical inference, pattern recognition, generalization) - Applaud creative solutions, even incorrect ones.

3. Input-Visual: sights, pictures, diagrams, symbols

\section{Presentation-Visual:} utilization of pictures, diagrams, films and demonstrations extensively

\section{Input-Auditory:} sounds, words

\section{Presentation -}

Verbal: having many lectures, readings and discussions

\section{Input-Visual:}

- Use pictures, schematics, graphs, and simple sketches liberally before, during and after the presentation of verbal material. Show films.

- Provide demonstrations, handson, if possible.

\section{Input-Auditory:}

- Use a lecture-style forum, presenting information by talking to their students. Regulating voice tone, inflection, and body language will help all students maintain interest and attention. Auditory learners succeed when directions are read aloud, speeches are required, or information is presented and requested verbally 
5. Input-Kinesthetic: taste, touch and smell

\section{Organization-} Inductive: a reasoning progression that proceeds from particulars (observations, measurements, data) to generalities (governing rules, laws, theories).

\section{Organization-}

Deductive: proceeding in the opposite direction, inferring principles; in deduction one deduces consequences.

\author{
5. Presentation- \\ Kinesthetic: using both \\ information perception \\ (touching, tasting, \\ smelling) and \\ information processing \\ (moving, relating, doing \\ something active while \\ learning) in the \\ instruction.
}

\section{Organization-}

Inductive: presenting particulars (observations, measurements, data) to generalities (governing rules, laws, theories). (Phenomena leading to principles) (Teachers may assign them to observe the things around them and draw inferences.)

7. Organization-

Deductive: presenting principles to phenomena.
5. Input-Kinesthetic:

- Have students engage with the learning activity such as in a science lab, drama presentation, skit, field trip, dance, or other active activity. A more hands-on approach: manipulatives and other "props" are incorporated into almost every subject

\section{Organization-Inductive:}

- Motivate learning. As much as possible, relate the material being presented to what has come before and what is still to come in the same course, to material in other courses, and particularly to the students' personal experience.

- Present theoretical material.

Then develop the theory

\section{Organization-Deductive:}

- Show how the theory or madcam be validated and deduce its consequences and present applications.

Statements designating each type of learning style, teaching style and teaching technique were developed. There were totally 44 items with an open-ended part for additional information (if any). Due to the fact that the participants included Thai, Vietnamese students and Thai Vietnamese and foreign instructors, the questionnaires were written in three languages, namely English, Thai and Vietnamese. (See Appendices A and B for examples of the questionnaires.) The complete sets of questionnaires were validated by three content experts in the fields of Applied Linguistics and Education for their examination of content relevance and appropriateness.

A 4 point rating scale format was applied in the two questionnaires. The even numbers of the scales deducted the neutral opinion so that the respondents' 
opinions would be specified on just one side. The scales used in the SPELS-TTQ were strongly agree (4), agree (3), disagree (2) and strongly disagree (1) respectively while the scales used in the TPES-TTQ included very often (4), often (3), sometimes (2) and seldom (1).

Table 2: Summary of the conceptual framework for developing the two questionnaires (Cont.)

$\begin{array}{llc}\text { Learning Style } & \begin{array}{l}\text { Corresponding } \\ \text { Teaching Style }\end{array} & \begin{array}{c}\text { Corresponding Teaching } \\ \text { Technique }\end{array}\end{array}$

8. Processing-Active:
doing something in the
external world with the
information -
discussing it or
explaining it or testing
it in some way.

8. Student
preparation-Active:
allowing students to
talk, move and reflect

8. Processing-Active:

- Balance material that emphasizes practical problemsolving methods

- Provide demonstrations, handson, if possible.

- Use computer-assisted instruction-sensors respond very well to it.

- Provide opportunities for students to do something active besides transcribing notes. Small-group brainstorming activities that take no more than five minutes are extremely effective for this purpose.

- Give students the option of cooperating on homework assignments to the greatest possible extent. Active learners generally learn best when they interact with others; if they are denied the opportunity to do so they are being deprived of their most effective learning tool.

\section{Processing-}

Reflective: examining and manipulating the information introspectively.

\section{Student} preparation-Passive: having students to watch and listen

\section{Processing-Reflective:}

- Balance material that emphasizes fundamental understanding.

- Do not fill every minute of class time lecturing and writing on the board. Provide intervalshowever brief-for students to think about what they have been told. 


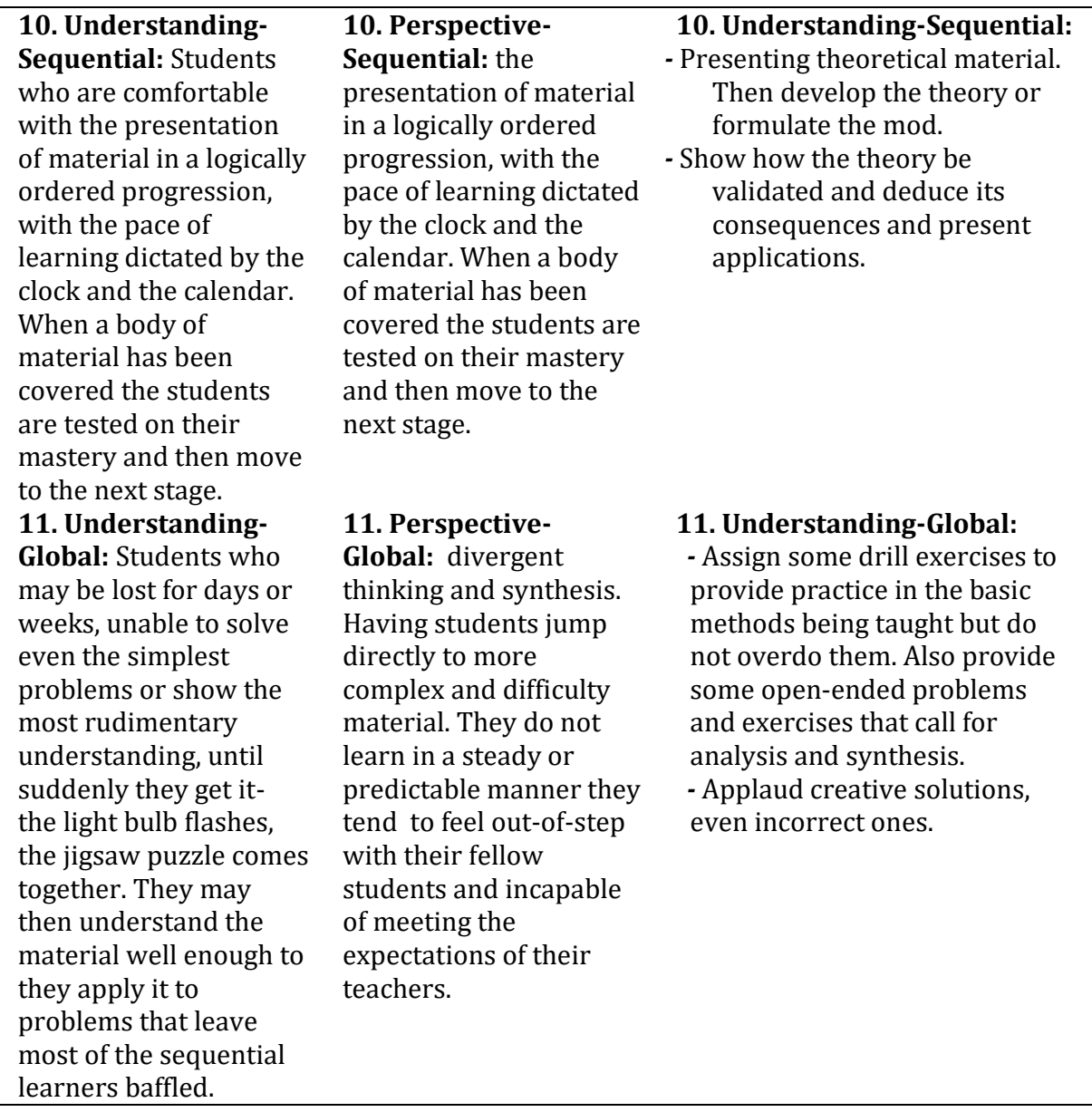

A pilot study was then conducted to try out the instruments, data collection methods and data analytical methods, after which some revisions were made. The reliability of the questionnaire was evaluated using the alpha coefficients. The values obtained were .81 and .83 for the SPELS-TTQ and the TPETS-TTQ respectively. The coefficients show that the two questionnaires contain high reliability.

As for the English proficiency test, the test was adopted from that of Nakhornsri, Panproegsa, Wimolsasem, Sangwirach and Makhphunthong's (2014) study which developed the English proficiency test and the descriptors for each level of the ability band for the students' English proficiency. Its writing and 
reading parts were used in this study. According to the levels of English proficiency, there were three levels, namely high, moderate, and low and these criteria were used to specify students' levels of English proficiency in this study.

\subsection{Research procedures}

The research was conducted through the following stages. Firstly, the student participants were asked to take the English Proficiency Test in order to classify their English proficiency levels. Then, the two questionnaires were distributed to all the participants. After that, data collection and data analysis were followed.

\subsection{Data Analysis}

The analysis procedures for each research question are discussed in turn as follows:

Data analysis for research question 1: Which English learning styles and teaching techniques are preferred by Thai and Vietnamese students?

The data from the SPELS-TTQs were analyzed by means of descriptive statistics (i.e. arithmetic mean and standard deviation).

Data analysis for research question 2: Which teaching styles and teaching techniques practiced by Thai and Vietnamese teachers can be matched with those preferred by the students?

The data from the TPETS-TTQs were analyzed by means of descriptive statistics (i.e. arithmetic mean and standard deviation), after which their findings were compared with those of the research question 1.

Data analysis for research question 3: Which English learning styles and teaching techniques are preferred by students with high level of English proficiency?

To categorize the student participants' English proficiency, the researcher followed the division of proficiency levels used in the study of Nakhornsri et al. (2014), which includes three different levels (i.e. low, moderate, and high). After that, the data obtained from the SPELSTTQs were analyzed to find out their preferred English learning styles and teaching techniques.

Data analysis for research question 4: What are the similarities of Thai and Vietnamese students' preferences for learning styles and teaching techniques?

The data from Thai and Vietnamese students and teachers obtained from the two research instruments were separately analyzed by means of descriptive statistics (i.e. arithmetic mean and standard deviation).

\section{Findings}

The results obtained from the analyses of the questionnaire data which address research questions 1-4 are presented in turn as follows: 
Research question 1: Which English learning styles and teaching techniques are preferred by Thai and Vietnamese students?

Since the questionnaire used for this research question includes 4 rating scales, the following criteria were used to interpret the findings:

3.26 - 4.00 means "strongly agree"; $\quad 2.51-3.25$ means "agree"

1.76 - 2.50 means "disagree"; $\quad 1.00-1.75$ means "strongly disagree"

Table 3: The learning styles preferred by Thai and Vietnamese students

\begin{tabular}{|l|c|c|c|}
\hline \multicolumn{1}{|c|}{ Learning Style } & $\bar{X}$ & S.D. & Interpretation \\
\hline Processing-active & 3.20 & .61 & agree \\
Input-kinesthetic & 3.12 & .56 & agree \\
Perception-sensory & 3.05 & .54 & agree \\
Organization-inductive & 3.05 & .60 & agree \\
Input-visual & 3.04 & .57 & agree \\
Organization-deductive & 3.04 & .59 & agree \\
Input-auditory & 3.03 & .65 & agree \\
Understanding-sequential & 3.02 & .60 & agree \\
Perception- intuition & 3.00 & .56 & agree \\
Understanding-global & 2.89 & .66 & agree \\
Processing-reflective & 2.86 & .66 & agree \\
\hline
\end{tabular}

From the above table, the majority of students rated Processing-active learning style the highest $(\bar{X}=3.20$, S.D. $=0.61$ ) whereas Processing-reflective learning style has the lowest mean ( $\bar{X}=2.86$, S.D. $=.66$ ).

Table 4: The teaching techniques preferred by Thai and Vietnamese students

\begin{tabular}{|l|c|c|c|}
\hline \multicolumn{1}{|c|}{ Teaching Techniques } & $\bar{X}$ & S.D. & Interpretation \\
\hline Processing-active & 3.20 & .61 & agree \\
Organization-inductive & 3.19 & .59 & agree \\
Organization-deductive & 3.12 & .62 & agree \\
Input-visual & 3.11 & .57 & agree \\
Perception- intuition & 3.10 & .56 & agree \\
Understanding-global & 3.07 & .63 & agree \\
Input-kinesthetic & 3.06 & .58 & agree \\
Understanding-sequential & 3.04 & .65 & agree \\
Perception-sensory & 3.01 & .61 & agree \\
Input-auditory & 2.97 & .63 & agree \\
Processing-reflective & 2.86 & .62 & agree \\
\hline
\end{tabular}


As for the teaching techniques, Thai and Vietnamese students rated Processingactive the highest ( $\bar{X}=3.20$, S.D. $=.61$ ) while Processing-reflective was reported as the lowest ( $\bar{X}=2.86$, S.D. $=.62$ ).

Research question 2: Which teaching styles and teaching techniques practiced by Thai and Vietnamese instructors can be matched with those preferred by the students?

To answer this research question, the students' preferred learning styles and the teachers' practiced teaching styles were reordered according to the mean scores from the highest to the lowest. The following interpretation criteria were used.
$3.26-4.00$ means "very often"
2.51 - 3.25 means "often"
1.76 - 2.50 means "sometimes"
1.00 - 1.75 means "seldom"

Whether the teaching styles would be considered to match with the learning styles depends on the same ranks they correspond to the teaching styles suggested by Felder (2002). The following table shows the match between the learning styles and the teaching styles.

In conclusion, the only matched pair between the learning styles preferred by Thai and Vietnamese students and those practiced by their teachers is Processingreflective learning style and Student preparation-passive.

For the match between teaching techniques preferred by students and practiced by teachers, Table 6 illustrates the matched pairs.

Table 5. The match between the learning styles preferred by Thai and Vietnamese students and those practiced by their instructors

\begin{tabular}{|c|l|l|l|c|}
\hline Rank & $\begin{array}{c}\text { Learning Style } \\
\text { preferred by students } \\
\text { rearranged according } \\
\text { to } \\
\text { the mean }\end{array}$ & $\begin{array}{c}\text { Correspon } \\
\text { ding } \\
\text { Teaching } \\
\text { Style } \\
\text { (Felder, } \\
\mathbf{2 0 0 2})\end{array}$ & $\begin{array}{c}\text { Teaching Style } \\
\text { practiced by } \\
\text { teachers rearranged } \\
\text { according to } \\
\text { the mean }\end{array}$ & $\begin{array}{c}\text { Compa } \\
\text { tibility }\end{array}$ \\
\hline 1 & $\begin{array}{l}\text { Processing-active } \\
(\bar{X}=3.20)\end{array}$ & $\begin{array}{l}\text { Student } \\
\text { participation- } \\
\text { active }\end{array}$ & $\begin{array}{l}\text { Presentation-visual } \\
(\bar{X}=3.50)\end{array}$ & $\mathrm{X}$ \\
\hline 2 & $\begin{array}{l}\text { Input-kinesthetic } \\
(\bar{X}=3.12)\end{array}$ & $\begin{array}{l}\text { Presentation- } \\
\text { kinesthetic }\end{array}$ & $\begin{array}{l}\text { Student preparation- } \\
\text { Active } \\
(\bar{X}=3.45)\end{array}$ & $\mathrm{X}$ \\
\hline
\end{tabular}




\begin{tabular}{|c|c|c|c|c|}
\hline \multirow[t]{2}{*}{3} & $\begin{array}{l}\text { Perception-sensory } \\
(\bar{X}=3.05)\end{array}$ & $\begin{array}{l}\text { Content- } \\
\text { concrete }\end{array}$ & \multirow{2}{*}{$\begin{array}{l}\text { Presentation- } \\
\text { kinesthetic } \\
(\bar{X}=3.15)\end{array}$} & $\bar{X}$ \\
\hline & $\begin{array}{l}\text { Organization-inductive } \\
(\bar{X}=3.05)\end{array}$ & $\begin{array}{l}\text { Organization- } \\
\text { inductive }\end{array}$ & & $\mathrm{X}$ \\
\hline \multirow[t]{2}{*}{4} & $\begin{array}{l}\text { Input-visual } \\
(\bar{X}=3.04)\end{array}$ & $\begin{array}{l}\text { Presentation- } \\
\text { visual }\end{array}$ & $\begin{array}{l}\text { Presentation-verbal } \\
(\bar{X}=3.13)\end{array}$ & $\mathrm{X}$ \\
\hline & $\begin{array}{l}\text { Organization-deductive } \\
(\bar{X}=3.04)\end{array}$ & $\begin{array}{l}\text { Organization- } \\
\text { deductive }\end{array}$ & $\begin{array}{l}\text { Perspective -Global } \\
(\bar{X}=3.13)\end{array}$ & $\mathrm{X}$ \\
\hline 5 & $\begin{array}{l}\text { Input-auditory } \\
(\bar{X}=3.03)\end{array}$ & $\begin{array}{l}\text { Presentation- } \\
\text { verbal }\end{array}$ & $\begin{array}{l}\text { Organization- } \\
\text { Inductive } \\
(\bar{X}=3.10)\end{array}$ & $\mathrm{X}$ \\
\hline \multirow[t]{2}{*}{6} & \multirow[t]{2}{*}{$\begin{array}{l}\text { Understanding- } \\
\text { sequential } \\
(\bar{X}=3.02)\end{array}$} & \multirow[t]{2}{*}{$\begin{array}{l}\text { Perspective- } \\
\text { Sequential }\end{array}$} & $\begin{array}{l}\text { Organization- } \\
\text { Deductive6 } \\
(\bar{X}=3.08)\end{array}$ & $\mathrm{X}$ \\
\hline & & & $\begin{array}{l}\text { Content-concrete } \\
(\bar{X}=3.08)\end{array}$ & \\
\hline 7 & $\begin{array}{l}\text { Perception- intuition } \\
(\bar{X}=3.00)\end{array}$ & $\begin{array}{l}\text { Content- } \\
\text { abstract }\end{array}$ & $\begin{array}{l}\text { Perspective- } \\
\text { Sequential } \\
(\bar{X}=2.95)\end{array}$ & $\mathrm{X}$ \\
\hline 8 & $\begin{array}{l}\text { Understanding-global } \\
\text { ( } \bar{X}=2.89 \text { ) }\end{array}$ & $\begin{array}{l}\text { Perspective- } \\
\text { global }\end{array}$ & $\begin{array}{l}\text { Content-abstract } \\
(\bar{X}=2.65)\end{array}$ & $\mathrm{X}$ \\
\hline 9 & $\begin{array}{l}\text { Processing-reflective } \\
(\bar{X}=2.86)\end{array}$ & $\begin{array}{l}\text { Student } \\
\text { participation- } \\
\text { passive }\end{array}$ & $\begin{array}{l}\text { Student preparation- } \\
\text { passive } \\
(\bar{X}=2.50)\end{array}$ & $\sqrt{ }$ \\
\hline
\end{tabular}

Note: $X=$ Not matched $/ \sqrt{ }=$ Matched $/ N A=$ Not Applicable

Table 6: The match between the teaching techniques preferred by Thai and Vietnamese students and those practiced by their instructors

\begin{tabular}{|c|l|l|l|c|}
\hline Rank & $\begin{array}{c}\text { Teaching } \\
\text { technique } \\
\text { preferred by } \\
\text { students } \\
\text { rearranged } \\
\text { according to } \\
\text { the mean }\end{array}$ & $\begin{array}{l}\text { Corresponding } \\
\text { Teaching Style } \\
\text { (Felder, 2002) }\end{array}$ & $\begin{array}{c}\text { Teaching } \\
\text { Technique } \\
\text { practiced by } \\
\text { teachers } \\
\text { rearranged } \\
\text { according to } \\
\text { the mean }\end{array}$ & $\begin{array}{c}\text { Compati } \\
\text { bility }\end{array}$ \\
\hline 1 & $\begin{array}{l}\text { Processing-active } \\
(\bar{X}=3.20)\end{array}$ & $\begin{array}{l}\text { Processing- } \\
\text { active }\end{array}$ & $\begin{array}{l}\text { Processing-Active } \\
(\bar{X}=3.33)\end{array}$ & $\sqrt{ }$ \\
\hline
\end{tabular}




\begin{tabular}{|c|c|c|c|c|}
\hline 2 & $\begin{array}{l}\text { Organization- } \\
\text { inductive } \\
(\bar{X}=3.19)\end{array}$ & $\begin{array}{l}\text { Organization- } \\
\text { inductive }\end{array}$ & $\begin{array}{l}\text { Input-visual } \\
(\bar{X}=3.27)\end{array}$ & $\bar{X}$ \\
\hline 3 & $\begin{array}{l}\text { Organization- } \\
\text { deductive } \\
(\bar{X}=3.12)\end{array}$ & $\begin{array}{l}\text { Organization- } \\
\text { deductive }\end{array}$ & $\begin{array}{l}\text { Perception-intuition } \\
(\bar{X}=3.19)\end{array}$ & $X$ \\
\hline 4 & $\begin{array}{l}\text { Input-visual } \\
(\bar{X}=3.11)\end{array}$ & Input-visual & $\begin{array}{l}\text { Perception-sensory } \\
(\bar{X}=3.03)\end{array}$ & $X$ \\
\hline 5 & $\begin{array}{l}\text { Perception- intuition } \\
(\bar{X}=3.10)\end{array}$ & $\begin{array}{l}\text { Perception- } \\
\text { intuition }\end{array}$ & $\begin{array}{l}\text { Organization- } \\
\text { Inductive } \\
(\bar{X}=3.00)\end{array}$ & $X$ \\
\hline 6 & $\begin{array}{l}\text { Understanding- } \\
\text { global } \\
(\bar{X}=3.07)\end{array}$ & $\begin{array}{l}\text { Understanding- } \\
\text { global }\end{array}$ & $\begin{array}{l}\text { Organization- } \\
\text { Deductive } \\
(\bar{X}=2.94)\end{array}$ & $X$ \\
\hline 7 & $\begin{array}{l}\text { Input-kinesthetic } \\
(\bar{X}=3.06)\end{array}$ & Input-kinesthetic & $\begin{array}{l}\text { Understanding- } \\
\text { Sequential } \\
(\bar{X}=2.89)\end{array}$ & $X$ \\
\hline 8 & $\begin{array}{l}\text { Understanding- } \\
\text { sequential } \\
(\bar{X}=3.04)\end{array}$ & $\begin{array}{l}\text { Understanding- } \\
\text { sequential }\end{array}$ & $\begin{array}{l}\text { Understanding- } \\
\text { Global } \\
(\bar{X}=2.88)\end{array}$ & $X$ \\
\hline \multirow[t]{2}{*}{9} & $\begin{array}{l}\text { Perception-sensory } \\
(\bar{X}=3.01)\end{array}$ & $\begin{array}{l}\text { Perception- } \\
\text { sensory }\end{array}$ & $\begin{array}{l}\text { Input-auditory } \\
(\bar{X}=2.86)\end{array}$ & $X$ \\
\hline & NA & $\mathrm{NA}$ & $\begin{array}{l}\text { Input-kinesthetic } \\
(\bar{X}=2.86)\end{array}$ & $X$ \\
\hline 10 & $\begin{array}{l}\text { Input-auditory } \\
(\bar{X}=2.97)\end{array}$ & Input-auditory & $\begin{array}{l}\text { Processing- } \\
\text { Reflective } \\
(\bar{X}=2.23)\end{array}$ & $X$ \\
\hline 11 & $\begin{array}{l}\text { Processing-reflective } \\
(\bar{X}=2.86)\end{array}$ & $\begin{array}{l}\text { Processing- } \\
\text { reflective }\end{array}$ & & $X$ \\
\hline
\end{tabular}

Note: $X=$ Not matched $/ \sqrt{ }=$ Matched $/ N A=$ Not Applicable

Regarding the match between students' preferred teaching techniques and teachers' practiced teaching techniques reported by Thai and Vietnamese students and instructors, it can be concluded that there is a matched pair, namely Processing-active and Processing-active.

Research question 3: Which English learning styles and teaching techniques are preferred by students with high level of English proficiency?

The findings of this research question are shown in Tables 7 and 8.

Table 7: The learning styles preferred by students with high level of English proficiency 
slovakEdu, o,z.

\begin{tabular}{|l|c|c|c|}
\hline \multicolumn{1}{|c|}{ Learning Style } & $\bar{X}$ & S.D. & Interpretation \\
\hline Processing-active & 3.38 & .66 & strongly agree \\
Input-auditory & 3.22 & .60 & agree \\
Input-kinesthetic & 3.19 & .62 & agree \\
Organization-inductive & 3.13 & .65 & agree \\
Organization-deductive & 3.13 & .67 & agree \\
Perception- intuition & 3.10 & .63 & agree \\
Understanding-sequential & 3.10 & .67 & agree \\
Input-visual & 3.09 & .67 & agree \\
Perception-sensory & 3.07 & .64 & agree \\
Understanding-global & 2.91 & .86 & agree \\
Processing-reflective & 2.90 & .77 & agree \\
\hline
\end{tabular}

It can be concluded that the majority of the students with high level of proficiency prefer Processing-active ( $\bar{X}=3.38$, S.D. =.66).

Table 8: The teaching techniques preferred by students with high level of English proficiency

\begin{tabular}{|l|c|c|c|}
\hline \multicolumn{1}{|c|}{ Teaching Technique } & $\bar{X}$ & S.D. & Interpretation \\
\hline Processing-active & 3.38 & .66 & strongly agree \\
Organization-inductive & 3.29 & .70 & strongly agree \\
Input-kinesthetic & 3.23 & .54 & agree \\
Organization-deductive & 3.16 & .64 & agree \\
Perception-sensory & 3.13 & .60 & agree \\
Input-visual & 3.13 & .61 & agree \\
Input-auditory & 3.12 & .63 & agree \\
Perception- intuition & 3.10 & .61 & agree \\
Understanding-global & 3.06 & .79 & agree \\
Understanding-sequential & 3.01 & .71 & agree \\
Processing-reflective & 2.93 & .74 & agree \\
\hline
\end{tabular}

The above table shows that students with high level of English proficiency prefer Processing-active ( $\bar{X}=3.38$, S.D. $=.66$ ).

Research question 4: What are the similarities of Thai and Vietnamese students' preferences for learning styles and teaching techniques?

To answer this research question, comparisons of the preferred learning styles and teaching techniques between Thai and Vietnamese students were made. The findings were illustrated in the following tables. 
Table 9: The comparison of the preferred learning styles between Thai and Vietnamese students

\begin{tabular}{|c|c|c|c|c|}
\hline Rank & $\begin{array}{c}\text { Learning Style } \\
\text { preferred by } \\
\text { Thai students } \\
\text { rearranged according } \\
\text { to } \\
\text { the mean } \\
\end{array}$ & Rank & $\begin{array}{l}\text { Learning styles preferred } \\
\text { by Vietnamese students } \\
\text { rearranged according to } \\
\text { the mean }\end{array}$ & $\begin{array}{l}\text { Simila } \\
\text { rity }\end{array}$ \\
\hline 1 & $\begin{array}{l}\text { Processing-active ( } \bar{X} \\
=3.21)\end{array}$ & 1 & Processing-active $(\bar{X}=3.16)$ & $\sqrt{ }$ \\
\hline 2 & $\begin{array}{l}\text { Input-kinesthetic ( } \bar{X} \\
=3.17)\end{array}$ & 2 & $\begin{array}{l}\text { Understanding-sequential ( } \bar{X} \\
=3.04 \text { ) }\end{array}$ & $X$ \\
\hline \multirow[t]{2}{*}{3} & Input-visual $(\bar{X}=3.09)$ & 3 & Input-auditory $(\bar{X}=2.98)$ & $X$ \\
\hline & $\begin{array}{l}\text { Organization-deductive ( } \\
\bar{X}=3.09)\end{array}$ & & NA & $X$ \\
\hline \multirow[t]{2}{*}{4} & $\begin{array}{l}\text { Perception-sensory ( } \bar{X} \\
=3.08)\end{array}$ & 4 & Perception-sensory $(\bar{X}=2.91)$ & $\sqrt{ }$ \\
\hline & $\begin{array}{l}\text { Organization-inductive ( } \\
\bar{X}=3.08)\end{array}$ & & $\begin{array}{l}\text { Organization-inductive ( } \bar{X} \\
=2.91)\end{array}$ & $\sqrt{ }$ \\
\hline 5 & Input-auditory $(\bar{X}=3.04)$ & 5 & Input-kinesthetic ( $\bar{X}=2.89)$ & $\boldsymbol{X}$ \\
\hline \multirow[t]{2}{*}{6} & $\begin{array}{l}\text { Perception-intuition ( } \bar{X} \\
=3.03 \text { ) }\end{array}$ & 6 & $\begin{array}{l}\text { Processing-reflective }(\bar{X} \\
=2.84)\end{array}$ & $X$ \\
\hline & NA & & $\begin{array}{l}\text { Understanding-global ( } \bar{X} \\
=2.84)\end{array}$ & $\boldsymbol{X}$ \\
\hline \multirow[t]{2}{*}{7} & $\begin{array}{l}\text { Understanding-sequential } \\
(\bar{X}=3.01)\end{array}$ & 7 & $\begin{array}{l}\text { Perception- intuition }(\bar{X} \\
=2.82)\end{array}$ & $X$ \\
\hline & NA & & Input-visual $(\bar{X}=2.82)$ & $X$ \\
\hline 8 & $\begin{array}{l}\text { Understanding-global ( } \\
\bar{X}=2.91 \text { ) }\end{array}$ & 8 & $\begin{array}{l}\text { Organization-deductive ( } \bar{X} \\
=2.79 \text { ) }\end{array}$ & $X$ \\
\hline 9 & $\begin{array}{l}\text { Processing-reflective ( } \bar{X} \\
=2.86)\end{array}$ & 9 & NA & $X$ \\
\hline
\end{tabular}

Note: $X=$ Different $/ \sqrt{ }=$ Similar $/ N A=$ Not Applicable

From the above table, it can be concluded, Thai and Vietnamese students similarly preferred Processing-active, Perception-sensory, and Organization-inductive while preferences for other types of learning styles were differently reported. 
Table 10. The comparison of the preferred teaching techniques between Thai and Vietnamese students

\begin{tabular}{|c|c|c|c|c|}
\hline Rank & $\begin{array}{c}\text { Teaching techniques } \\
\text { preferred by } \\
\text { Thai students } \\
\text { rearranged } \\
\text { according to } \\
\text { the mean }\end{array}$ & Rank & $\begin{array}{l}\text { Teaching techniques } \\
\text { preferred by } \\
\text { Vietnamese students } \\
\text { rearranged according to } \\
\text { the mean }\end{array}$ & $\begin{array}{c}\text { Simila } \\
\text { rity }\end{array}$ \\
\hline 1 & $\begin{array}{l}\text { Organization-inductive } \\
(\bar{X}=3.23)\end{array}$ & 1 & $\begin{array}{l}\text { Processing-active }(\bar{X} \\
=3.16)\end{array}$ & $X$ \\
\hline \multirow[t]{2}{*}{2} & $\begin{array}{l}\text { Processing-active }(\bar{X} \\
=3.21)\end{array}$ & 2 & Input-visual $(\bar{X}=3.02)$ & $X$ \\
\hline & NA & & $\begin{array}{l}\text { Understanding-global }(\bar{X} \\
=3.02)\end{array}$ & $X$ \\
\hline \multirow[t]{3}{*}{3} & $\begin{array}{l}\text { Perception- intuition ( } \\
\bar{X}=3.14 \text { ) }\end{array}$ & 3 & $\begin{array}{l}\text { Input-kinesthetic }(\bar{X} \\
=3.00)\end{array}$ & $X$ \\
\hline & $\begin{array}{l}\text { Organization-deductive } \\
(\bar{X}=3.14)\end{array}$ & & $\begin{array}{l}\text { Organization-deductive ( } \\
\bar{X}=3.00)\end{array}$ & $\sqrt{ }$ \\
\hline & NA & & $\begin{array}{l}\text { Organization-inductive }(\bar{X} \\
=3.00)\end{array}$ & $X$ \\
\hline 4 & Input-visual $(\bar{X}=3.13)$ & 4 & $\begin{array}{l}\text { Perception-sensory }(\bar{X} \\
=2.95)\end{array}$ & $X$ \\
\hline 5 & $\begin{array}{l}\text { Understanding- } \\
\text { sequential }(\bar{X}=3.09)\end{array}$ & 5 & $\begin{array}{l}\text { Perception- intuition }(\bar{X} \\
=2.91)\end{array}$ & $X$ \\
\hline 6 & $\begin{array}{l}\text { Understanding-global ( } \\
\bar{X}=3.08 \text { ) }\end{array}$ & 6 & Input-auditory $(\bar{X}=2.86)$ & $X$ \\
\hline 7 & $\begin{array}{l}\text { Input-kinesthetic }(\bar{X} \\
=3.07)\end{array}$ & 7 & $\begin{array}{l}\text { Processing-reflective }(\bar{X} \\
=2.75)\end{array}$ & $X$ \\
\hline 8 & $\begin{array}{l}\text { Perception-sensory }(\bar{X} \\
=3.02)\end{array}$ & 8 & $\begin{array}{l}\text { Understanding-sequential } \\
(\bar{X}=2.84)\end{array}$ & $X$ \\
\hline 9 & $\begin{array}{l}\text { Input-auditory }(\bar{X} \\
=2.99)\end{array}$ & 9 & NA & $X$ \\
\hline 10 & $\begin{array}{l}\text { Processing-reflective ( } \\
\bar{X}=2.89 \text { ) }\end{array}$ & & NA & $X$ \\
\hline
\end{tabular}

Note: $X=$ Different $/ \sqrt{ }=$ Similar $/ N A=$ Not Applicable

It can be summarized that regarding the similarity of the preferred teaching techniques, Organization-deductive was found to be preferred by both Thai and 
Vietnamese students, whereas other types of teaching techniques were ranked in different orders of preference.

\section{Discussion}

This section provides an interpretation of the findings. The five findings are discussed as follows:

\subsection{The preferred learning styles and teaching techniques of Thai and Vietnamese students}

Interestingly, the results of this present study revealed that the preferences for learning styles and teaching techniques reported by student participants of both nationalities are congruent. Processing-active learning style which refers to processing information actively was rated with the highest mean score. This reflects the fact that the majority of students like to discuss or talk about the lessons they are learning. They tend to feel more comfortable with active experimentation; so, they may not learn much in situations that require them to be passive such as most lectures. Data from the open-ended part support this conclusion. Below are some examples of students' preferences on the Processingactive learning style:

\section{Example 1:}

"I don't like reading assignment. It's quite boring and repeated. I'm full of energy when joining in active games in class." (Code: VN 1)

Example 2:

"I enjoy being involved in active activities in class. I prefer games requiring groupwork skills." (Code: TH 2)

This finding is also consistent with the analysis of Akkakoson (2011) who concluded that Group learning style is the most preferred. Oxford (2003) explained the characteristics of this learning style as a preference for studying with others. Group studying allows students to feel comfortable and and it is the best way for them to acquire knowledge. They also value class interaction and class work with other students and they remember information when they work with two or three classmates.

When investigating students' preference for teaching techniques, the finding is in accordance with the preferred learning styles. The students in this study would like their instructors to provide them material that emphasizes practical problemsolving methods. Demonstrations and hands-on could allow them to better understand the lessons. Importantly, they would like to have opportunities to do something active instead of transcribing notes. Instructors, therefore, should give 
them an option for cooperating in homework assignments as they can learn best when interacting with others.

\subsection{The match of the students' preferred learning styles and the instructors' practiced teaching styles}

Since learning styles and teaching styles are closely interrelated, the style similarities between students and instructors can consistently and positively affect students' learning achievement. Brown (1994) stated that the match between students' learning styles and teachers' teaching styles can increase students' motivation, performances and achievements.

However, the findings of this study report that there is only one matched pair, Processing-reflective and Student preparation passive which was rated as the $9^{\text {th }}$ rank. It can be interpreted that students have the least favor to this style and so do the instructors who use this teaching style the least.

Although the preferred learning styles and practiced teaching styles which appeared in the higher rankings were not exactly compatible. The findings also show that Processing-active was ranked first as students' the most preferred learning style. Its corresponding teaching style should be Student participationactive which was placed second in the order of instructors practiced teaching styles. This result indicates that even though instructors do not rate Student participation-active the highest practiced style, they also find it important and tend to implement this style very often.

\subsection{The match of the students' preferred teaching techniques and the instructors' practiced teaching techniques}

A match was found in terms of the students' preferred teaching techniques and the instructors' practiced teaching techniques. The students rated techniques used for Processing-active learning style as their most preferred teaching techniques and the teachers reported that the techniques they practiced very often in class were for Processing-active learning style. This indicates that the teachers emphasize practical problem-solving methods and tend to provide more demonstrations. However, when considering other rankings, styles of both parties were all mismatched.

This match would be more effective if instructors are also aware of their students' needs, capacity, and potential. Myers and McCaulley (1985) recommended teachers to use an assessment instrument to investigate these factors. It may help to reveal students' preferences, especially their learning styles. Based on the learning style assessment results, the instructors can alter and accommodate appropriate techniques to serve their students' preferences. 


\subsection{The preferred learning styles and teaching techniques of students with high levels of English proficiency}

As Reid (1987) suggested that a match between students' and teachers' style preferences could result in better achievement, equal educational opportunities, and positive attitudes to learning, the construct of styles in teaching and learning should not be overlooked. Stebbins (1995) supports that mismatching could cause a negative impact on the students' attitude and learning process while matching could improve their attitude, behavior, motivation, and learning eventually.

Results of the current study suggest that Processing-active is the most preferred learning style and the most preferred teaching technique of students with high levels of English proficiency. This is in accordance with the most practiced teaching technique of the instructors. As Processing-active was ranked second, this can be concluded that the students with high levels of English proficiency tend to prefer learning/teaching styles which are compatibly given by the instructors. This is posited by Felder and Silverman's work (1988) which reveals that the compatibility of the learning styles and teaching styles can provide an optimal learning environment for most students in a class. Once an instructor attempts to match teaching styles or techniques to students' preferred learning styles, it can help to promote understanding in a classroom. Hence, the compatibility can lead to a higher level of understanding and learning achievement (Wittmann-Price \& Godshall, 2009).

\subsection{Similarities of the preferred learning styles and teaching techniques between Thai and Vietnamese students}

The findings of present study reveal that Thai and Vietnamese students prefer similar learning style, Processing active. This could reflect the ways students process information generally. Felder (2002) explains that active learners prefer to do something in the external world with the information. They like to discuss or explain things. Importantly, they feel more comfortable with active activities; so, they can work well in groups.

This result can be explained by the students' awareness of the importance of English. They realize that English has long played an important role in many developing countries where it is modelled as a lingua franca or a shared language of communication (Kirkpatrick, 2007). Apart from the processes of globalized networks in which English plays a part, Thailand and Vietnam are entering the ASEAN Economic Community (AEC) by 2015 with an aim to create ASEAN economic community, free trade area, comprehensive investment area, trade in services, single aviation market, free trade agreements with other countries and ASEAN sociocultural community (Thailand Convention and Exhibition Bureau, (2009). For this, the students of both nationalities realize that English inevitably 
become an important language of communication within this region. English ability could provide them great opportunities, especially those who look for a job.

Besides a similar preference on Processing-active learning style, the students also reported similar preferences on Perception-sensory ( $4^{\text {th }}$ rank) and Organization-inductive ( $5^{\text {th }}$ rank). As a sensory learner, students preferentially learn things through senses, for example observing, gathering data [20]. They prefer facts, data, and experimentation. Regarding Organization-inductive learning style, inductive students will be comfortable when information is organized inductively, or when a reasoning progression proceeds from particulars to generalities. They will learn best when observing the world around them and draw inferences (2002).

The teaching techniques for Organization-deductive learning styles are preferred by both Thai and Vietnamese students. This means they prefer to be presented by theory and assigned to read or listen to explanations with examples. Teachers should inform them directly what they are going to learn. When learning grammar, they prefer to pay little attention to meaning. As a result, the practice should be often mechanical.

\section{Implications}

The findings of this study are significant in several ways.

First, in terms of theoretical significance, the findings can contribute to the curriculum development. The data about students' preferred learning styles can be included when designing a course or preparing lesson plans.

For the preferred teaching style, suggestions can be made for English teachers so that they would realize students' preferred learning styles and their own comfort zone. This would assist these teachers to teach outside their comfort level to match the students' preferred learning styles.

In addition, the findings could better promote the courses provided for students. By understanding the learning style make-up of the students enrolled in the courses, faculty should be able to adjust their modes of content delivery to match student preferences and maximize student learning.

Finally, since this research includes students and teachers from Thailand and Vietnam, better understanding between language learning natures of people from these two countries can be established. Importantly, it can develop the bilateral relationships with respect to education and other co-operative activities, which could be implemented in the future.

\section{Acknowledgements}

I wish to express my appreciation to the Faculty of Applied Arts, King Mongkut's University of Technology North Bangkok (KMUTNB) for providing the fund to support this study. Also, I am very grateful to a number of students at 
KMUTNB, Thailand and students at ISTNU, Vietnam who sacrificed hours to participate in this study.

I would like to thank Ms. Phuong Thao Nguyen who assisted translating the questionnaires into Vietnamese and collecting the data. Importantly, this study would not be possible without great assistance and participation from the colleagues at the faculty of Applied Arts, KMUTNB. Their friendship and professional collaboration have meant a great deal to me.

\section{References}

Akkakoson, S. (2011). Learning and teaching style preferences in EFL. Journal of the Worldwide Forum on Education and Culture,)31(, 66-78.

Alkhasaweh, I. M., Mrayyan, M. T., Docherty, C, Alashram, S., \& Yosef, H. (2008). Problem-based learning (PBL): Assessing students' learning preferences using VARK. Nurse Education Today, 28, 572 -579.

Barbe, W. B. \& Milone, M. N. (1981). What We Know About Modality Strengths. Educational Leadership, 70 (1), 378-380.

Bastable, S. B. (2008). Nurse as educator: Principles of teaching and learning for nursing practice (3rd ed.). Boston: Jones and Bartlett Publishers.

Brown, H. (1994). Principles of language learning and teaching. Englewood Cliffs, NJ: Prentice Hall Regents.

Carbo, M., Dunn, R. \& Dunn K. (1986). Teaching Students to Read Through Their Individual Learning Styles. Prentice-Hall.

Cohen, A. D. \& Weaver, S. J. (2005). Styles and strategies-based instruction: A teachers' guide. CARLA Working Paper Series, A rewritten version of paper \#7, Univesity of Minnesota.

Colbert, J. A., Brown, R. S., Choi, H., \& Thomas, S. (2008). An investigation of the impacts of teacher-driven professional development on pedagogy and student learning. Teacher Education Quarterly, 35(2), 135-154.

Dullien, S. \& Priewe, J. (2010). Teaching Tools: A Digital Handbook for Academic Lecturers. Retrieved from www.vi.unctad.org

Dunn, R.,k \& Griggs, S. (1988). Learning styles: Quiet revolution in American secondary schools. Reston, VA: National Association of Secondary School Principals.

Ehrman, M. (1996). Understanding second language learning difficulties. Thousand Oaks, CA: Sage.

Felder, M. R. (2002). Learning and teaching styles in Engineering education. Engr. Education, 78(7), 674-681

Felder, R. M., \& Silverman, L. K. (1988). Learning and teaching styles in engineering education [Electronic Version]. Engr. Education, 78(7), 674-681. Retrieved on December 29th, 2013 from: http://www4.ncsu.edu./unity/lockers/users/f/felder/public/Papers/LS1988.pdf 
Fischer, B. B. \& Fischer, L. (1979). Styles in Teaching and Learning. Educational Leadership 36 (January), 251.

Jonassen, D. (1999). Designing Constructivist Learning Environments. In C. M. Reigeluth (Ed.), Instructional-design theories and models: Vol. II. A new paradigm of instructional theory (pp. 215-239). Mahwah, NJ: Lawrence Erlbaum Associates.

Jung, C. G. (1971). Psychological Types. Princeton University Press: Princeton, N.J. Katsioloudis, P. \& Fantz, T.D. (2012). A Comparative Analysis of Preferred Learning and Teaching Styles for Engineering, Industrial, and Technology Education Students and Faculty. Journal of Technology Education. 23(2), 61 -69.

Katz, A. (1996). Teaching style: A way to understand instruction in language classrooms. In K. M. Bailey and D. Nunan (Eds.), Voices from the Language Classroom (pp.57-87). Cambridge: Cambridge University Press.

Keefe, J. (1987). Learning style theory and practice. Reston, VA: NASSP.

Kirkpatrick, A. (2007). Implications for English language teaching. In A. Kirkpatrick, World Englishes: Implications for international communication and English language teaching (pp. 184 - 197). Cambridge: Cambridge University Press.

Kinsella, K. (1995). Understanding and empowering diverse learners. In J. Reid (Ed.), Learning styles in the ESL/EFL classroom (170-194). Boston: Hcinlc.

Mayer, R. E. (1996). Multimedia learning: Are we asking the right questions? Educational Psychologist, 32, 1-19.

Mulalic, A., Shah, P. M., \& Ahmad, F. (2009). Perceptual learning styles of ESL students. European Journal of Social Sciences, 7(3), 101-113.

Myers, I. \& McCaulley, M. (1985). Manual: a guide to the development and use of the Myers-Briggs Type Indicator. Palo Alto, CA: Cons ulting Psychologists Press.

Nakhornsri, S. Panproegsa, S. Wimolkasem, N. Sangwirach, T. \& Mahaphunthong, C. (2014). The Development of the Quality and the Ability Band for the English Proficiency Tests. KMUTNB: Thailand

Noom-ura, S. (2013). English-Teaching Problems in Thailand and Thai Teachers'Professional Development Needs. English Language Teaching, 6, 11.

Nunan, D. (2003). Action Research in the Classroom in J. C. Richards and D. Nunan (eds.).

Oxford, R.L., (2003). Language Learning Styles and Strategies: An Overview. GALA. Oxford, R.L., \& Anderson, N. (1995). State of the art: A crosscultural view of language learning styles. Language Teaching, 28(4), $201-215$.

Provost, J., \& Anchors, S. (1987). Applications of the Myers-Briggs type indicator in higher education. Palo Alto, Calif: Davies-Black Publishing.

Reid, J. M. (1995). Learning styles in the ESL/EFL students. TESOL Quarterly, 21 (1), 87 - 111. Rochester Institute of Technology. (n.d.). Retrieved on April 1 1st, 2014 from: http://wallacecenter.rit.edu/tls/teaching- learning-styles 
Reid, J. M. (1987). The learning style preferences of ESL students. TESOL Quarterly, 21(1), 87-111.

Stafford, R. Dunn, K. J. \& Bacon, A. (1993). Teaching Secondary Students Through Their Individual Learning Styles. Prentice-Hall.Thai-AEC, (n.d.). Retrieved on April 1st, 2014 from: http://www.thai-aec.com/139\#ixzz2y5BAMwll

Stebbins, C. (1995). Culture-specific perceptual-learning style preferences of postsecondary students of English as a second language. In J. Reid (Ed.), Learning styles in the ESL/EFL classroom (pp. 108-117). Boston: Heinle.

Thailand Convention and Exhibition Bureau. (2009). Thai and ASEAN community. Retrieved from http://www.tceb.or.th/exhibition/why-thailand/businessopportunities.html

The ASEAN Secretariat. (n.d.). Retrieved on April 1st, 2014 from: http://www.asean.org/communities/asean-economic-community

Van Van, H. (2010). The current situation and issues of the teaching of English in Vietnam. 立命館言語 文化研究, 22, 1.

Vu, P.H. (2013). Asia News Network. Retrieved on April 1st, 2014 from: http://www.asianewsnet.net/AEC-SPECIAL-REPORT--VIETNAM-Boldreforms-needed-55493.html

Wiriyachitra, A. (2002). English language teaching and learning in Thailand in this decade. Thai TESOL Focus, 15(1), 4-9.

Wittmann-Price, R. A., \& Godshall, M. (2009). Strategies to promote deep learning in clinical nursing courses. Nurse Educator, 34(5), 214-216.

\section{Contact:}

Nakhornsri Supalak

King Mongkut's University of Technology North Bangkok

Faculty of Applied Arts, Department of Languages

Pracharat 1 Road, Bangkok, Thailand

supalak.n@arts.kmutnb.ac.th 


\section{Appendix A. \\ Example of Questionnaire on Students' Preferred English Learning Styles and Teaching Techniques}

Direction: Place a check in the appropriate space after each statement according to the meaning of each scale below. This item survey is not timed. Respond to each statement as honestly as you can. 4 = Strongly agree 3 =agree $2=$ disagree 1 =strongly disagree คำสั่ง: กรุณาทำเครื่องหมายถูกลงในช่องตามความหมายของแต่ละสเกลต่อไปนี้ สามารถตอบแบบสอบถามได้โดยไม่จำกัดเวลา กรุณาตอบตามความเป็นจริง
$4=$ เห็นด้วยอย่างยิ่ง
$3=$ เห็นด้วย
$2=$ ไม่เห็นด้วย

$1=$ ไม่เห็นด้วยอย่างยิ่ง

Hướng dẫn: Đánh dấu vào ô trống thích hợp theo các mức phân loại dưới đây. Việc trả lời các câu hỏi này sẽ không giới hạn thời gian. Vui lòng trả lời trung thực, khách quan nhất bạn có thể.

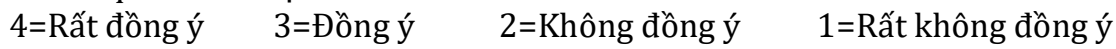

\begin{tabular}{|l|l|l|l|l|}
\hline \multicolumn{1}{|c|}{ Learning Style/รูปแบบการเรียน/Phương pháp học } & $\mathbf{4}$ & $\mathbf{3}$ & $\mathbf{2}$ & $\mathbf{1}$ \\
\hline $\begin{array}{l}\text { 1. I am good at memorizing facts and } \\
\text { data./ฉันจำข้อเท็จจริงและข้อมูล ได้เป็นอย่างดี/Tôi có khả năng về } \\
\text { việc ghi nhớ các dữ kiện và dữ liệu. }\end{array}$ & & & & \\
\hline $\begin{array}{l}\text { 2. I am very careful and patient with details, but may be } \\
\text { slow./ฉันใส่ใจและอดทนกับรายละเอียด } \\
\text { จึงทำให้บางครั้งใช้เวลานาน/Tôi rất cẩn thận và kiên nhẫn với các } \\
\text { chi tiết, tuy nhiên có thể xử lý hơi chậm. }\end{array}$ & & & & \\
\hline
\end{tabular}




\section{Appendix B.}

\section{Example of Questionnaire on Teacher's Practiced English Teaching Styles and Teaching Techniques}

Direction: Place a check in the appropriate space after each statement according to the meaning of each scale below. This item survey is not timed.

Respond to each statement as honestly as you can.

$4=$ Very often $3=$ Often $2=$ Sometimes $1=$ Seldom

คำสั่ง: กรุณาทำเครื่องหมายถูกลงในช่องตามความหมายของแต่ละสเกลต่อไปนี้ สามารถตอบแบบสอบถามได้โดยไม่จำกัดเวลา กรุณาตอบตามความเป็นจริง

$$
4=\text { บ่อยมาก } 3=\text { บ่อย } 2 \text { = บางครั้ง } 1 \text { = แทบจะไม่ }
$$

Hướng dẫn: Đánh dấu vào ô trống thích hợp theo các mức phân loại dưới đây. Việc trả lời các câu hỏi này sẽ không giới hạn thời gian. Vui lòng trả lời trung thực, khách quan nhất bạn có thể.

4=Rất đồng ý ～3=Đồng ý ～2=Không đồng ý ～1=Rất không đồng ý

\begin{tabular}{|c|c|c|c|c|}
\hline Teaching Style/ รูปแบบการสอน /Phương pháp giảng dạy & 4 & 3 & 2 & \\
\hline $\begin{array}{l}\text { 1. I like to have students memorize facts and } \\
\text { data./ ฉันชอบให้ผู้เรียนจดจำข้อเท็จจริงและข้อมูลต่าง ๆ /Tôi } \\
\text { thích truyền đạt cho học sinh cách ghi nhớ thông tin và } \\
\text { dữ kiện }\end{array}$ & & & & \\
\hline $\begin{array}{l}\text { 2. I prefer to provide students with a lot of details and have } \\
\text { them time to study very careful slowly./ } \\
\text { ฉันชอบให้รายละเอียดจำนวนมากและให้เวลาผู้เรียนในการศึกษาร } \\
\text { ายละเอียดเหล่านั้นอย่างค่อยเป็นค่อยไป/Tôi thích cung cấp } \\
\text { cho học sinh nhiều chi tiết và cho họ thời gian để tư duy } \\
\text { kĩ càng, cẩn thân. }\end{array}$ & & & & \\
\hline
\end{tabular}

